\title{
Thracian Tracio
}

\author{
Wojciech Sowa \\ Adam Mickiewicz University \\ wojsow@amu.edu.pl
}

\begin{abstract}
Thracian belongs to the group of languages spoken over the entire period of Antiquity in the areas of south-eastern Europe (mostly the Balkans) and which, like other vernaculars spoken in this and neighbouring areas, had died out by the end of the Roman period leaving but scanty evidence. This chapter provides an introduction into the state of our current knowledge about the Thracian language and epigraphy and the perspectives of research of this language. Since our comprehension and understanding of grammatical system of Thracian is limited, the current knowledge of the language makes any translation of attested inscriptions impossible. It is however expected that the progress in studying development and history of the Greek script may provide us with new and relevant data for interpretation of Thracian.
\end{abstract}

Keywords: Balkan Indo-European. Ancient languages of the Balkans. Thracian. Epigraphy. Onomastics.

Resumen: El tracio pertenece al grupo de lenguas habladas a lo largo de la Antigüedad en las áreas del sudeste de Europa (principalmente los Balcanes) y que, al igual que otras lenguas vernáculas habladas en esta área y sus alrededores, habían desaparecido al final del periodo romano, dejando escasas evidencias. Este capítulo proporciona una introducción al estado de la investigación sobre esta lengua. En tanto que nuestra comprensión del sistema gramatical tracio es limitada, el conocimiento actual de esta lengua impide la traducción de las inscripciones que se han conservado. Sin embargo, se espera que los avances en el estudio del desarrollo e historia de la escritura griega pueda proveer de nuevos datos relevantes para la interpretación del tracio.

Palabras clave: Indoeuropeo balcánico. Antiguas lenguas de los Balcanes. Tracio. Epigrafía. Onomástica.

Recepción: 30.09.2019 | Aceptación: 11.03.2020 
Thracian belongs to the group of languages spoken over the entire period of Antiquity in the areas of south-eastern Europe (mostly the Balkans: from the river Haliacmon north of Olympus to the Black Sea and from the north of the Aegean Sea to the Carpathian Mountains) and which, like other vernaculars spoken in this and neighbouring areas, had died out by the end of the Roman period leaving but scanty evidence.

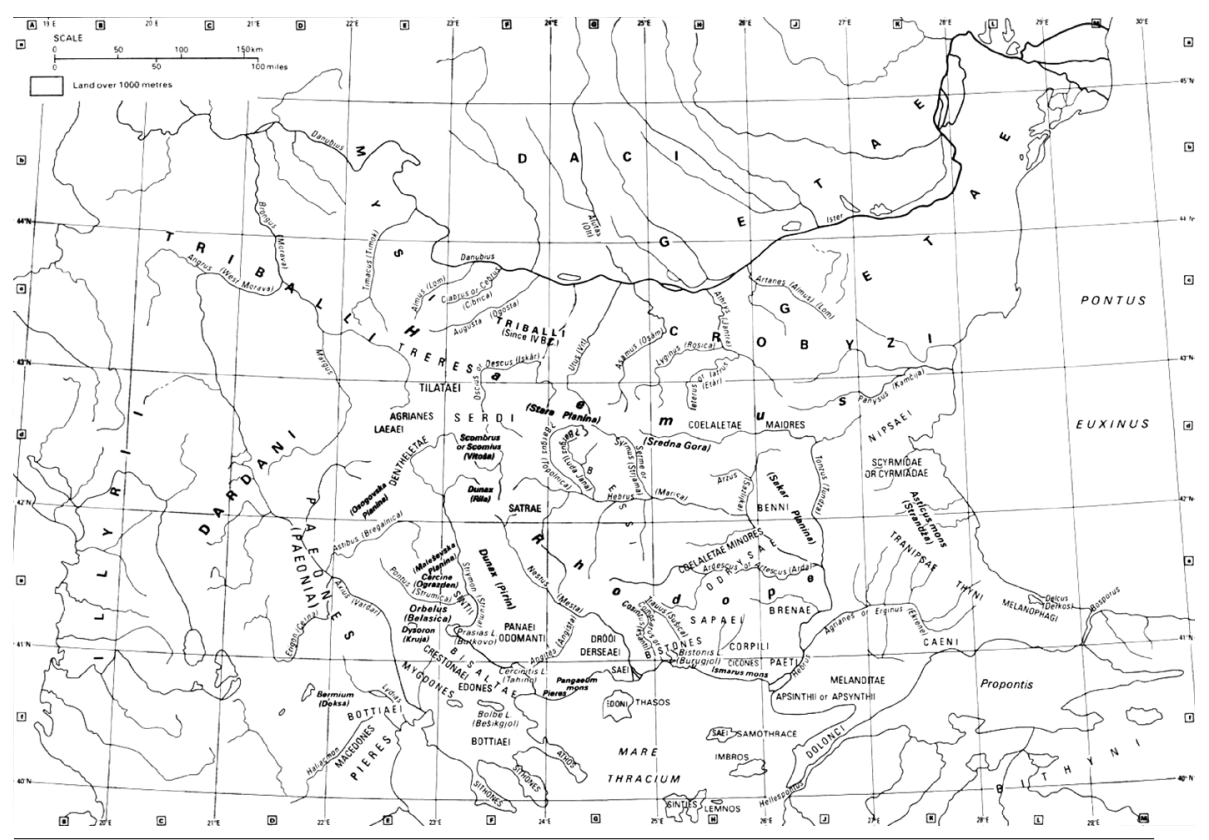

Fig. 1. Thrace and the Thracian tribes before the Persians (Boardman et al. 1991, 592-593).

The Ancient Greek tribes came into contact with Thracians (understood as a separate ethnic-linguistic unity) very early on; the contacts seem to have been already well established by the Mycenaean period. ${ }^{1}$ Among the evidence supporting this claim is the attested variation of dialectal names of

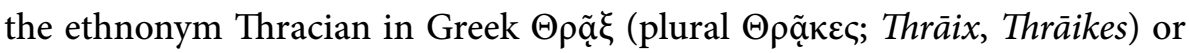

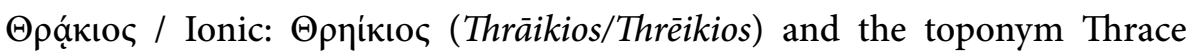

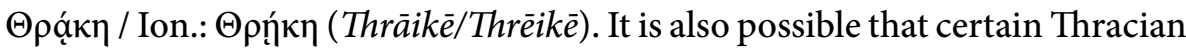
groups took part in the early Greek migrations and then settled in North and central Greece; such a tradition is attested by ancient authors whose testimony seems quite trustworthy ( $c f$. Strab. 7.7.4). The Thracians, as one the northern neighbours of the ancient Greeks, have always been present both in Classical 
mythology and in historical records of Greek cities and Roman expansion in the Balkans; they influenced Greek culture and religion in considerable ways. Some traces of religious and cultural influence can be detected even in the most archaic form of Greek culture: the cults of Ares and Dionysus seem to have been either of Thracian origin or influenced by Thracian culture. The mythical traditions of Orpheus, Thamyris, and Eumolpus testify to the same historical connection, which lasted throughout Greek history until the Hellenistic and Roman periods.

The first historical record of the Thracians is found in the Iliad, where they are described as allies of the Trojans in the Trojan War against the Achaeans. The Thracians were depicted as being fond of weapons and horses. Homer refers to Thrace as the "home of fast horses" and "mother of sheep", the Thracian are, moreover, "lance bearers" and "war chariot fighters", "shining brightly like the sun on the battlefield". Homer also gives us their geographical location, which parallels the historical data. Thracians inhabited parts of the ancient provinces of Thrace, Moesia, Macedonia, Dacia, Scythia Minor, Sarmatia, Bithynia, Mysia, Pannonia, and other regions of the Balkans and Bithynia. Essentially, the area of Thracian cultural influence extended over most of the Balkans region, reaching the Getae north of the Danube, extending probably as far east as the river Bug and including Pannonia in the west. This is probably why the ancient authors used to treat them as the second largest population on earth, after the Indians ( $c f$. Hdt. 5.3).

Divided into separate tribes (around 200), the Thracians were regarded as being warlike tribes. They did not manage to form a lasting political organization until the Odrysian state was founded in the fifth century BC, and a strong Dacian state only appeared north to the Danube in the first century BC, during the reign of King Burebista. Often depicted as barbarians, blue-eyed and red haired, ferocious and bloodthirsty and unrestrained in drinking, they were also seen as lovers of dance, instrumental music and singing (Orpheus). They possessed skilled craftsmen (especially regarding metal, gold and silver), and were masters of horses. ${ }^{2}$

2 For a general introduction to the history, archaeology, problems of Thracian identity, and epigraphic context $c f$. Valeva, Nankov \& Graninger 2015; cf. also Mihailov 1991, 591-618 for the early history of the region. 

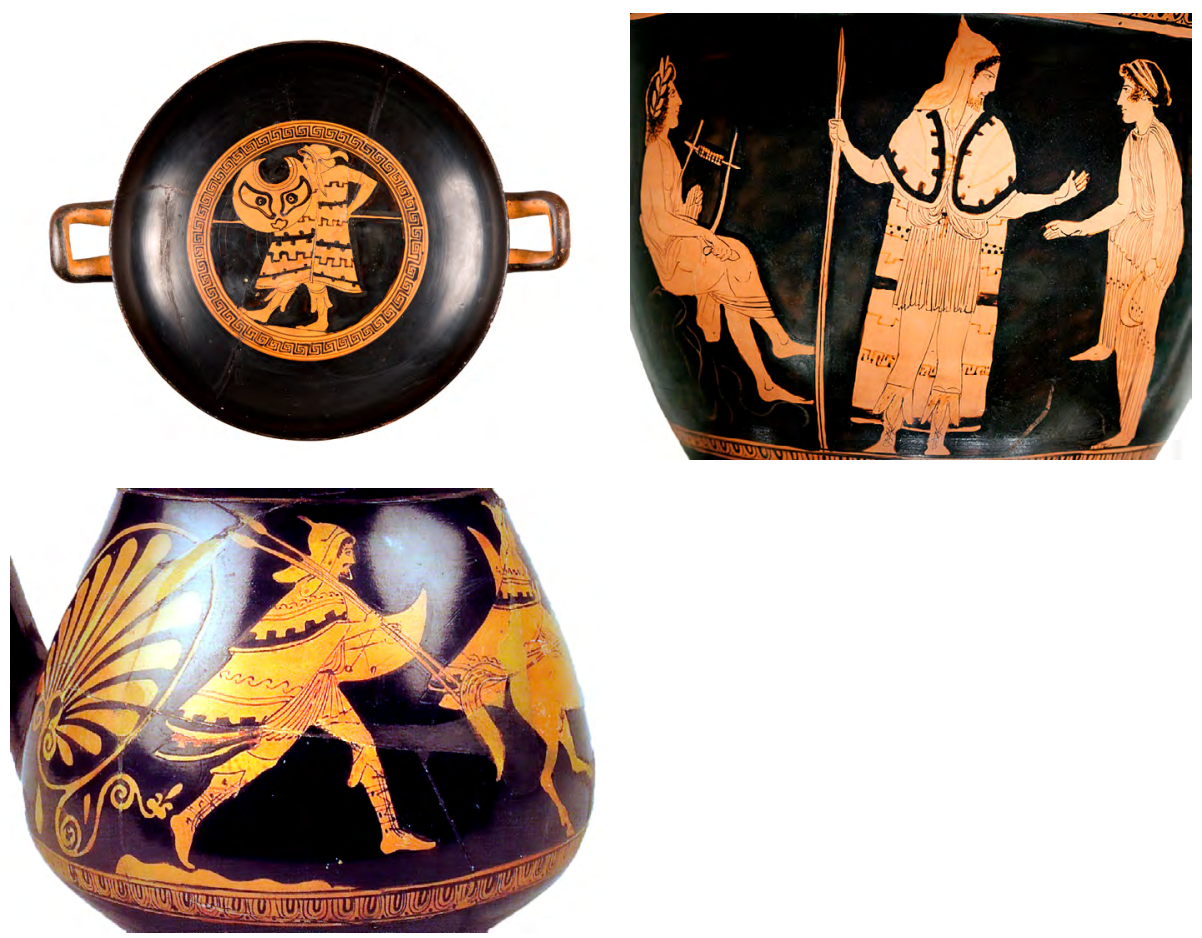

Figs. 2-4. Ancient depictions of Thracian warriors on an Attic red-figured ceramic: a peltast, with a characteristic hat, crescent shaped shield and high boots, ca 550 BC (Harvard University, Arthur M. Sackler Museum, Robinson Collection 1959.219. () President and Fellows of Harvard College, Harvard University, Arthur M. Sackler Museum, Robinson Collection); Orpheus among the Thracians - krater by the Painter of London E 497, ca 440 BC (Metropolitan Museum, Fletcher Fund, 24.97.30); a Thracian warrior with pelta (shield) and spears 475-435 BC (Archaeological Museum, Sozopol, inv. No. 261).

Given the scarcity of the material, it is extremely difficult to date Thracian as a language. It seems however that one can claim with relative certainty that the language was spoken through the Iron Age and into the Roman Era. There are examples of the Linear B forms from Crete which have been interpreted as Thracian names, $c f$. e.g. o-du-ru-we (Dat./Loc.sg.) KN C 902.6, (Gen.sg.)

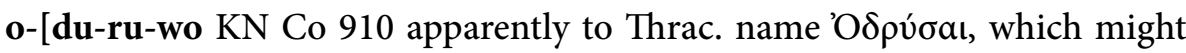
well point to the existence of Thracian as a separate linguistic unit in the chronology comparable to those of Mycenaean Greek (Hajnal 2003, 134). If we assume that the hypothetical Balkan linguistic unity (irrespective of genetic or more typological sorts) was still present around $2000 \mathrm{BC}$, we may claim that, after the first wave of migration of the Proto-Greek tribes, the other Balkan groups (Proto-Thracian/Proto-Macedonian/Proto-Phrygian) occupied the historical regions of Macedonia and Thracia, and the migrations 
around $1200 \mathrm{BC}$ caused some movements to push the ancestors of Phrygians to the Asia Minor and the Doric tribes to the South. ${ }^{3}$ In such a hypothetical scenario, Thracians would have remained in their historical settlements, or even have spread to the North and East. Thracian remained the predominant language in the Central Balkans possibly until the Slavic invasion. For example, the Slavic version of the place name Plovdiv seems to continue the Thracian form Pulpudeva rather than the Greek Phillippopolis, despite the strong Hellenization of the material culture in the area; ${ }^{4}$ the quick Romanization after Roman conquest would indicate influence of both languages (Greek and Latin). The singular mention of the monks speaking "Bessian" language in one of the monasteries in the Sinai in the $6^{\text {th }}$ cent. (around 570 AD), by Antonius Placentinus is worth noting. Later Symeon the Metaphrast $\left(10^{\text {th }}\right.$ cent.) in his biography of Saint Theodosius the Cenobiarch (423-529) claimed that Thracian was spoken in a monastery, built on Mount Sinai, when Theodosius visited (i.e. in the $5^{\text {th }}$ cent.): "There were four churches (...), one for each of the three nations of which his community was chiefly composed, each speaking a different language (...). The nations into which the community was divided were the Greeks, who were by far the most numerous, and consisted of all those that came from any provinces of the empire; the Armenians, with whom were joined the Arabians and Persians; and, thirdly, the Bessi, who comprised all the northern nations below Thrace, or all who used the Runic or Sclavonian tongue. Each nation sung the first part of the mass to the end of the gospel in their own church, but after the gospel all met in the church of the Greeks, where they celebrated the essential part of the sacrifice in Greek and communicated all together...." This reference could suggest a scenario where the remnants of Thracian were still in use by the time of the appearance of Slavic tribes in the Balkans.

Thracology, understood as a historical discipline studying the history, archaeology, and language of the Thracians, was born in late $19^{\text {th }}$ cent. and is linked to the name of the Czech-Austrian scholar Wilhelm Tomaschek (Vilém Tomášek), who published in Vienna (1893-1894) a seminal book in two volumes, titled: Die alten Thraker. Eine ethnologische Untersuchung (Sitzungsbe-

3 Cf. sketch of the historical-archaeological context in Hajnal 2003, 131-134.

$4 C f$. however alternative solution proposed by Matzinger 2016, 30, who suggests that the original Thracian name could have survived in the local use next to the "official" Greek form. 
richte der philosophisch-historischen Classe der Kaiserlichen Akademie der Wissenschaften). The first volume was devoted to the historical interpretation of the distribution and culture of the Thracian tribes (as attested in ancient sources). The second volume (in two parts) presented a collection of all remnants of the Thracian language known at that time. Along with Tomaschek's tradition, most of the studies on Ancient Balkans had been carried out at the University of Vienna until the end of World War II. Interest in the ancient history and archaeology of the Balkan regions grew rapidly after the war, when research was continued in Balkan centres at the Universities of Bucharest, Sofia, Belgrade, and Skopje. Systematic archaeological excavations carried out in the region began to yield a considerable number of new findings, revealing the half-forgotten culture of the fringes of ancient Greek civilization. The mandate of the Institute of Thracology, founded in 1972 in Sofia as a division of Bulgarian Academy of Sciences, was to develop an integrated approach to the study of material culture, history, and linguistic heritage of Thracians and other Balkan tribes. Among the scholars who contributed to linguistic studies on the Thracian language one must name in the first place Paul Kretchmer, but the contributions of Bulgarian and Romanian scholars were invaluable. It is sufficient to name Vladimir Georgiev, Ion I. Russu, Dimityr Detschev, Georgi Mihailov or Alexander Fol, who proposed the notion of "Mycenaean Thrace" to explain the relative cultural unity between the Thracians and the Mycenaeans. It seems, however, that after a relative boom in the study Old Balkan languages in the 60s and 70s, research in this area subsided, due to unsatisfactory results. ${ }^{6}$ Nonetheless, the ongoing excavations carried out in Bulgaria in recent years revealed spectacular testimonies to the material aspects of the Thracian culture: architecture and painting, some of them, e. g., the famous Mound from Kazanlyk became part of the World's UNESCO Heritage, testifying to the close cultural bounds existing between Greeks and their northern neighbours.

6 Thracian language has always been a topic subjected to exaggerations and speculations, many publications rely on rather old, methodologically outdated literature. For the classical presentation of Thracian $c f$. Tomaschek 1893-94; Detschev 1957; Russu 1969; Duridanov 1985. The studies of Thracian language formed one of the main interests of the scientific activity of Bulgarian linguist Vladimir Georgiev, whose works, even if from today's perspective appear outdated, have, for many years, been treated as a golden standard in Thracology, e.g. Georgiev 1977. As a good introduction to the problem of the linguistic situation on the Balkan Peninsula in the Antiquity one still can use Katičić 1976 and two chapters by Crossland 1982, 834-849 and Polomé 1982, 866-876. 


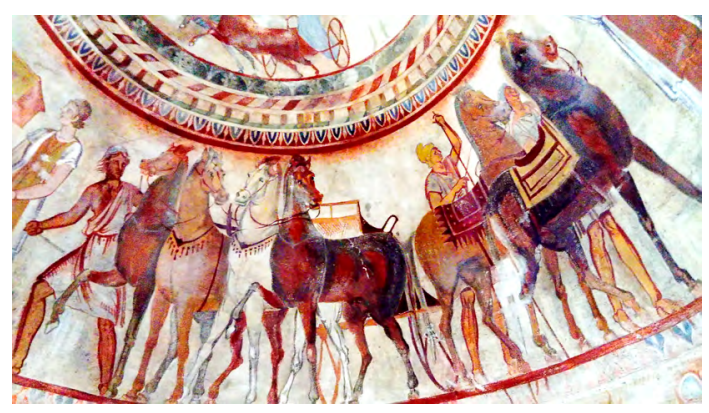

Figs. 5-6. Details from the Thracian burial mound from Kazanlyk ( $4^{\text {th }}$ cent. BC).

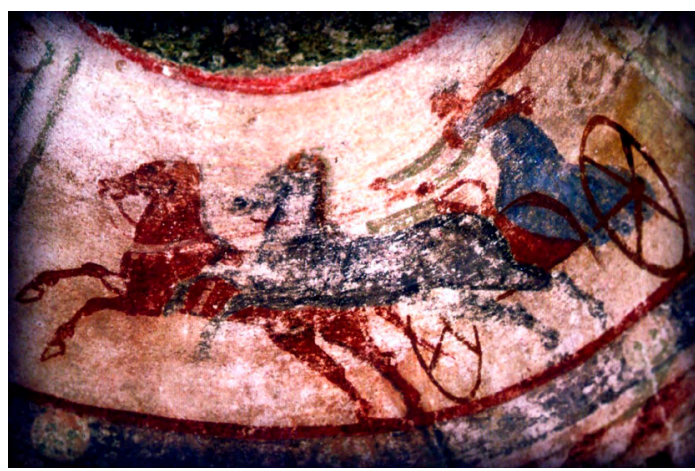

\section{The language}

\subsection{Phonology}

Thracian seems to yield the so-called "satem" development of inherited IE palatal consonants ${ }^{*} k$ and ${ }^{*} \dot{g}^{(h)}$, which in many cases render $s$ and $z$ respectively in Thracian; $c f$. onymic element -esp-, -esb-, or even - ezb- very probably to IE ${ }^{\star} h_{1} e k$ 'uos 'horse'; the toponomastic element -diza, -os if really related

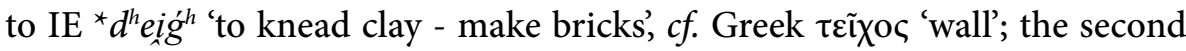
element of the compound name -zenis as in Diazenis, Briazenis, compared

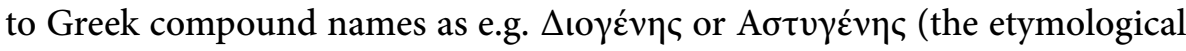
and even typological connection seems quite certain there). It seems, however, that even if one traditionally assumed Thracian to be one of the so-called "satem" languages, the number of "centum" forms, i.e. the treatments of IE palatalised ${ }^{*} k / g / g^{h}$ as "plain" velars $k$ and $g$ can also be observed: $c f$. placename Akmonia (next to Asamus, both forms maybe to IE ${ }^{\star} h_{2}$ ekmo- 'stone'); name of the Dacian king Decebalus (if compared to OInd. daśabala 'having the strength of 10 men'); $\Delta \varepsilon \kappa a i v \varepsilon o \varsigma$ (if Thracian and not Greek) < IE * dekm- '10', placename "A $\gamma$ poupov (Iron Gate on the Danube) if from ${ }^{\star} h_{2} e n g$ - 'narrow', 


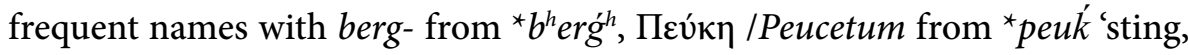
needle tree' or one of the best known examples of the Thracian glosses, which is

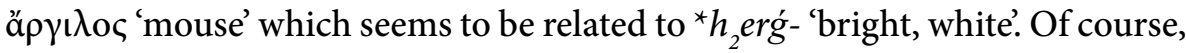
some such forms may simply be foreign elements in Thracian (especially of Greek, but also of possible Celtic origin), $c f$. name Tri-kornion if compared to *kornu- 'horn', which looks like a Celtic element in the Balkans (Katičić 1976, 143f.; Brixhe 1997, 197f.; Matzinger 2016, 28, cf. however Brixhe 2018, 1853 who contests this traditional classification). ${ }^{7}$

\subsection{Consonant shift}

One of the difficulties in interpreting the Thracian consonant system is the presence of the mediae aspiratae series (i.e. aspirated voiceless stops) in such

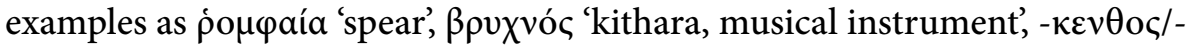
$\kappa \varepsilon v \theta \eta \varsigma$ (onymic element). It seems that the use of the signs $\varphi, \theta$, $\chi$ should be rather seen as a peculiarity of Greek orthography trying to render original Thracian forms. It seems more probable that the original IE mediae aspiratae and mediae fall together into one unaspirated series, $c f$. gloss $\beta \rho o v ̃$ o $\varsigma$ and placename $\Delta$ á $\tau$ ov (<IE. ${ }^{*} d^{h} e h_{1}$ - 'set, place'). Contrary to claims often made in earlier literature, Thracian does not register the so-called consonant shift or consonant mutation (Lautverschiebung), as attested in the forms of reduction of ${ }^{\star} b^{h} / d^{h} / g^{h}$ to $b / d / g$, but also ${ }^{\star} b / d / g>p / t / k$ and ${ }^{\star} p / t / k>p^{h} / t^{h} / k$ (Brixhe 1997, 198f.; Brixhe 2018, 1852; cf. discussion in Matzinger 2016, 28f. with further literature). Of course, it is very difficult to state anything precise about the phonetic value of Thracian judging only from the forms written in either Greek or Latin scripts (with their own specific conventions). It seems, however, that no examples of systematic or regular change as quoted above can be observed, in contrast to Germanic or Armenian, where a regular change of ${ }^{\star} b / d / g>p / t / k$, etc. can easily be noted. In Thracian, there are too many cases of exemption

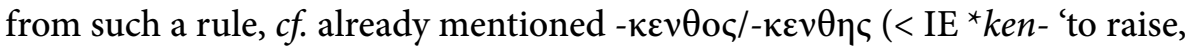
spring, begin'), very frequent place name element -apa ( $<{ }^{\star} h_{2} a p$ - 'water'), or a name Dios (as an element in compounds Dio- $\left(<{ }^{\star}\right.$ diio-), which always yield

7 It seems however, that this traditional classification of the IE languages has recently been abandoned- the centum-satem-division could be interpreted rather as an areal phenomenon, a sort of common phonetic ability, which then had been developed in some branches of the IE family in an independent way; the change $*|k|>$ sibilant (generally regarded as an innovation) seems to had been consistently carried out only in the Indo-Iranian group, all other so called "satem" languages yield a certain number of centum elements. 
a stable orthography. Therefore, as suggested above, one should rather think of a peculiarity of script (if Thracian phonological system did not include the voiceless aspirated consonants, the use of Greek signs designed for them was redundant; such signs might have been used also to render regular unaspirated voiceless stops); one could also speculate that there might have been some specific element of Thracian articulation attached to such consonants, which would require a special orthography (Matzinger, 2016).

The IE labiovelars also develop in a non-unified way: it seems that the

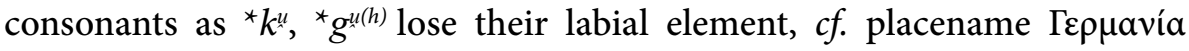

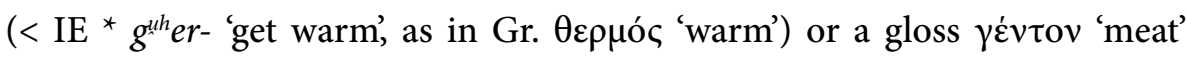
( $<\mathrm{IE}{ }^{\star} g^{\text {uh }}$ en- 'beat'); even here, however, one could find counter examples. The rather problematic evidence cannot be easily interpreted. It seems that, in fact, the labiovelars in Thracian have been partially delabialized, partially palatalized. The coexistence of the toponyms as Germisara, Zermizegra and Zarmizegetusa can point to the same process as attested in Alb. zjarm and Arm. jerm (both from IE ${ }^{\star} g^{\text {uh }}$ ermó-), namely to the tendency to palatalise inherited labiovelars when followed by front vowels (which seems to be a non-trivial common feature of the Balkan Indo-European dialectal group, v. infra). ${ }^{8}$

Other phenomena are difficult to interpret due to variable orthography as well; it seems that the $\mathrm{IE}^{\star} o$ develops either to Thracian $a$, when we compare the examples of morphemes used to form masculine names in -as Bastas,

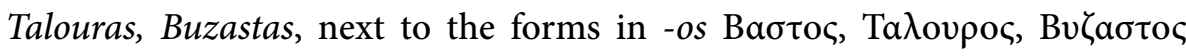
(the latter occur more frequently in Greek sources) or the presence of /a/ in the river names attested in the Thracian territory, as e.g. Пáva , etc., if they should be etymologized as related to < ${ }^{*}$ pon- ( $c f$. the name of a Roman province Pannonia). ${ }^{9}$ On the other hand, it has been assumed that the name of one of the most important Thracian stems Odrysae, Odrysai could contain the original ${ }^{*} / o$ / if interpreted as 'forest people' ${ }^{\star} h_{2} o-d r u-s^{\circ}$ (Matzinger 2016, 29).

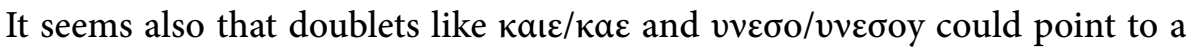
sort of monophthongisation of the original diphthongs (Brixhe 2018, 1853).

\footnotetext{
$8 C f$. the evidence for such languages as Albanian, Armenian, Ancient Greek dialects, Thracian and Macedonian areal, Messapic and Tocharian in Sowa 2009, 269-272 with discussion and further literature.

9 Cf. Anreiter 2001, 110.
} 


\subsection{Morphology and syntax}

Hardly anything can be said about Thracian morphology. We are not able to say anything about Thracian declension or conjugation; the same holds true of syntax. It seems, however, that one little piece of evidence can be drawn from dedicatory inscriptions found in 1988 in Zone, in the area of the sanctuary of Apollo. They are dated mostly to the $6^{\text {th }}$ cent. BC. Some inscriptions are monolingual, and some Greek-Thracian bilingual $\left(5^{\text {th }}-4^{\text {th }}\right.$ cent. $\left.\mathrm{BC}\right)$. Among

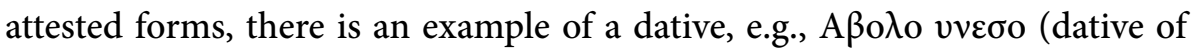

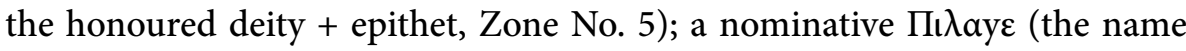
of a funder of an inscription), and a verb kate. This is same sentence as in

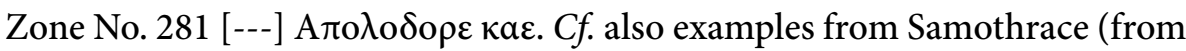

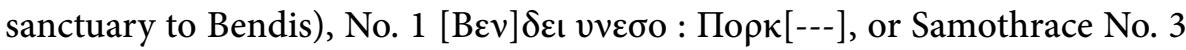

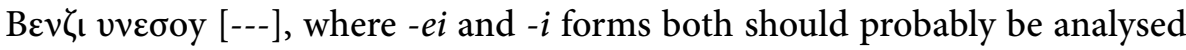
as datives as well (yielding the recipient of the dedication; Brixhe 2018, 1852; Brixhe 2006, 131f.).

One could maybe note various vowel changes, as, e.g. raising of mid-vow-

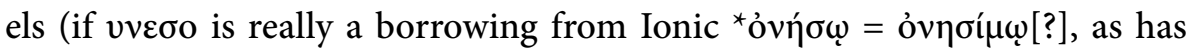
been recently suggested), or a reduction of final unaccented /o/ to a sort of

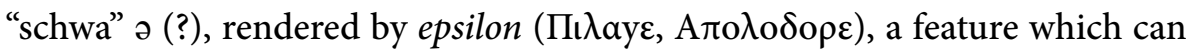
be found in Greek inscriptions from Thessaly, Thessaloniki or Thasos (Brixhe 2018, 1853).

If $\kappa a \iota \varepsilon / \kappa a \varepsilon$ can be interpreted as a reliable example of a verbal form one could observe the absence of the augment (which is otherwise attested in Greek, Armenian and Phrygian). ${ }^{10}$

\subsection{Dialectal variation?}

One of the traditional problems of Thracian scholarship has been the question of the position of Dacian in relation to Thracian and the other Old Balkan languages. Dacian (referred sometimes as Geto-Dacian, due to apparently linguistic-cultural unity of the Getae and Dacians, by the ancient authors), a contemporary, neighbouring language, attested in the north of the Thracian zone, was probably spoken by many tribes in south-eastern Europe between the Danube, Northern Carpathians, the Dniester River, the Balkans, and the Black Sea shore. Dacian had become established as the predominant

10 For the evidence and discussion on use of an augment in Phrygian $c f$. Sowa 2008, 98, 100f., 104 and 106. 
language north of the Danube in Dacia probably around $1000 \mathrm{BC}$ and south of the river, in Moesia, before $500 \mathrm{BC}$. It has been regarded as closely related to Thracian. The most important question is whether one should treat Dacian as a separate, independent IE language of the Balkans or simply as a Thracian dialectal variation. This problem cannot be solved at present due to insufficient evidence, which consists in one inscription with a reference to the name of a king Decebalus (...) DECEBALUS PERSCORILO, nowadays interpreted as a Latin inscription "Decebalus \{fecit\} per Scorilo"; this inscription contains the native Dacian personal name adopted into Latin inflection and uses of the preposition "per" incorrectly with dative/ablative (instead of expected accusative) - if one assumes that Scorilo is a form to the nominative Scorilus (Russu 1979, 43-46).

The other material is typical of fragmentary attested languages and consists of glosses (in this case the names of plants attested in the works by Dioskurides and Pseudo Apuleius $-1^{\text {st }}$ and $4^{\text {th }}$ cent. CE respectively) and personal or place names. From such evidence, hardly any conclusions can be drawn. It seems further that, in this case, all assumptions have been proposed on the basis of etymologies only. Thus, it has been suggested that the IE ${ }^{*}$ develops to

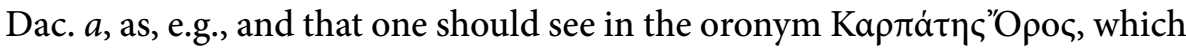
should then be analysed as ${ }^{\star} k a$ r p $\bar{a}-<{ }^{\star} k o ́ r p \bar{a}$ - 'fissured rock' < IE ${ }^{\star}(s) k$ erp- 'to cut from' (cf. also Alb. karpë 'rock'), and the IE labiovelars as e.g. ${ }^{\star} g^{u h}$ is then

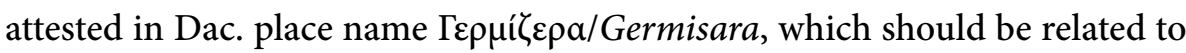
IE root ${ }^{\star} g^{\text {uh }}$ er- 'to be warm'. It also seems that Dacian (similarly to Thracian) should be considered a satem language if the place name Aizisis/Azizis really should be understood as derived from the IE ${ }^{\star} h_{2} a i \hat{g}_{\text {- }}$ 'goat', but probably alternative etymologies are also possible. (Matzinger 2016, 32 and 35)

When discussing the Dacian problem, one of the interesting arguments is the onomastics. Namely, it seems that there is a complementary distribution of the elements used by Thracian and Dacian onomastics: the place names of settlements in the Thracian core territory are mostly using the element -bria, -diza, or -para, which have not been attested to the North of the Danube, whereas the "formal" equivalent in Dacian territory seems to be -dava/-deva in the second element of the compound (see below). This distribution is very interesting, however, sporadically -dava/-deva names are also found to the South (cf. Pulpudeva, Bulg. Plovidv), and we do not know much about the exact semantics of the element (Duridanov 1985, 126f.; Brixhe 1997, 194; Matzinger 2016, 32). Consequently, this evidence seems insufficient to claim 
the independent status of Dacian. The territory of Dacians was frequented by other people: Celtic tribes, Greeks, Scythians in the east, and Bastarnae in the north-east. After the Roman conquest of Moesia and the establishment of the Danube as the new frontier in the years 29-26 BC, an intensive period or Romanization started, and numerous Roman military garrisons and veteran colonies were established. It seems that, by $200 \mathrm{AD}$, the Dacian regions north of the Danube experienced the same fate. Indeed, after the Roman campaigns, Dacian tribes were exposed to strong Romanisation which brought about the domination of the Latin language in the regions occupied by the Romans. By the end of the $3^{\text {rd }}$ cent. the lands to the North of the Danube had fallen under the political domination of various Germanic-speaking groups (mostly Goths), which continued until ca. $500 \mathrm{AD}$. It is difficult to determine whether the Dacian language was still spoken by Dacian tribal groups (e.g. in the eastern part of the Carpathians), although it is generally believed that the language (as in case of Thracian) became extinct by the beginning of the Slavic migration, around $600 \mathrm{AD}$.

\section{The inscriptions}

It is difficult to give the exact number of known extant Thracian inscriptions (especially since in some cases it is even impossible to interpret the document as an example of Thracian language). What we can assume to be remnants of Thracian has been attested in two longer inscriptions, one inscription fragment, small documents, and many graffiti on pottery. Most of them can be dated back to the sixth to fourth centuries BC. This collection does not include the coin legends bearing the names of Thracian kings or the Thracian names attested on various artefacts (see above). One has to bear in mind, that no printed corpus exists, which would gather all fragments that could be tentatively interpreted as "Thracian". Especially in the case of stone fragments from Zone on the Aegean shore, the attribution of documents to the Thracian language should not be considered certain.

From all epigraphic sources, only two can be called the "real" inscriptions, yielding a couple of sentences written in Thracian, and not just names or some sort of obscure onomastics (?) formulas. The first inscription is known under the name of Ezerovo Ring, because it had been incised on the golden ring and has been known since $1912 ;{ }^{11}$ the second one is a stone document known

11 As already rendered by the name itself, the inscription had been written on the surface of the ring made of gold, which was found during the excavations of a burial mound 

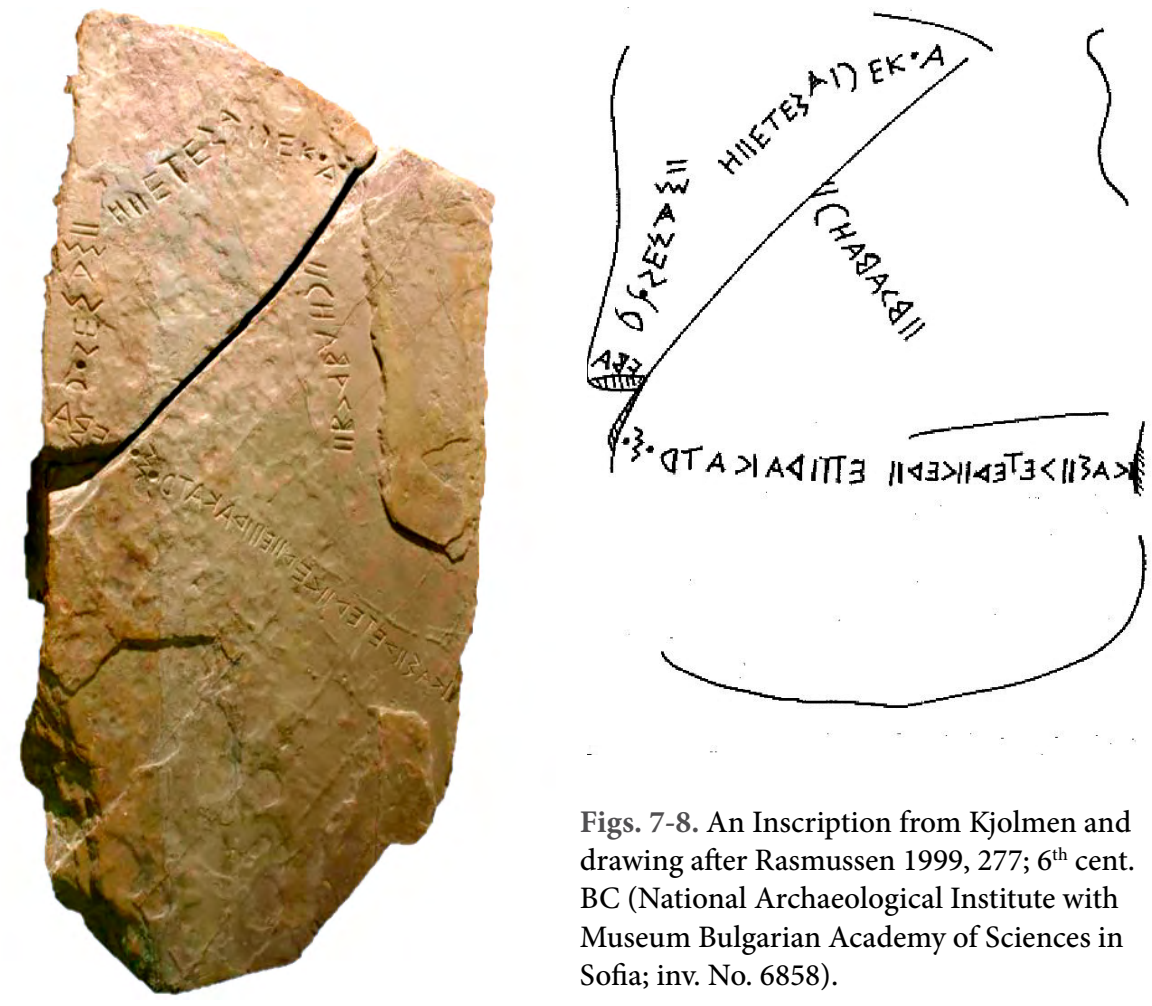

Figs. 7-8. An Inscription from Kjolmen and drawing after Rasmussen 1999,$277 ; 6^{\text {th }}$ cent. BC (National Archaeological Institute with Museum Bulgarian Academy of Sciences in Sofia; inv. No. 6858).

near the village of Ezerovo, Plovdiv district (now in National Archaeological Institute with Museum Bulgarian Academy of Sciences in Sofia inv. No. 5271). The ring was found in a burial mound; the pieces of jewellery and luxury goods, including a golden diadem, a round bronze mirror in an archaic Greek style, a small spoon, two triangle plates made of gold. The remnants of a bronze dish, and a broken armband made of bronze also found on the site would suggest funerary goods belonging to a member of the local Thracian upper class, but we are not sure whether the burial was made for a person of male or female sex. Both Detchev and Georgiev wanted to relate the object (ring) to a burial, based on the archaeological context of the find; they believed that the purpose of the ring was to accompany the deceased into the underworld and quoted the famous depiction of Thracian burial rituals given by Herodotus (5.5).

The inscription consists of a text in eight irregular lines and comprises 61 letters in total engraved on a surface of the ring, the last line having already been written on the rim. There is no standard approved edition of the document and the readings of the document differ to much extent between scholars, $c f$. Georgiev 1938, 184-192; Detschev 1957, 883; Rasmussen 1999, 287-292. The writing is easily read, the direction is retrograde, the text is in scriptio continua, and no word-division marks can be observed. We could transliterate text in the following way: PO $\Lambda$ I TENEA $\Sigma \mathrm{N} /$ EPENEATI $\Lambda$ /

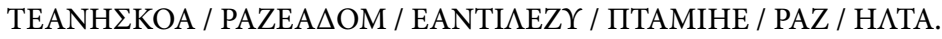


as the inscription from Kjolmen, probably a grave stone (?), which has been known to the scientific community since $1965 .^{12}$ There are slight differences to be observed between these two. The archaeological and epigraphical context allow us to postulate the chronology: the inscription form Kjolmen should probably be dated as older, to the $6^{\text {th }}$ century BC and the Ezerovo Ring should be dated into $4^{\text {th }}$ century BC.

One stone, probably funerary, inscription dated to the $5^{\text {th }}$ cent $\mathrm{BC}$ from Kjolmen (Bulgaria, vid. infra).

Fragments of four stone inscriptions from Zone (Eastern Thrace in Greece IAegThr 376-378) dated to the fourth century BC (Thracian provenance not assured).

A "bilingual" document in Greek and probably Thracian (cf. IAegThr 427, Thracian provenance not assured - the Greek name Menandros is followed by a sequence of signs with no marked boundaries between singular words, which does not seem to yield any known Greek word OTРЕГГЕ $\Delta$ ENA $\Sigma E \Delta$ [---]. One fragment of stone inscription from the island of Samothrace, dated to the $4^{\text {th }}$ cent. BC - the text is certainly not Greek, but the fragment is linguistically not usable (Thracian provenance not assured). ${ }^{13}$

Some examples of inscriptions on gold are the rings from Ezerovo (Bulgaria) bearing a text (figs. 9-10) and Duvanlii (Arabadzhiyskata Mogila, Plovidv area) bearing a Thracian (?) word (?) (fig. 11). ${ }^{14}$ On silver, four inscrip-

12 The Kjolmen inscription is a stone slab with incised letters on a stone plate (broken in the upper part) which was found lying above a grave excavated at the village of Kjolmen, district of Preslav (North-East of Bulgaria). The inscription has been found at the necropolis, in the centre of a burial mound. There are suggestions that the stele is a tombstone of a fallen soldier rather than a dedicatory document. The text had been written in a script using the archaic shape of Greek letters, singular sequences had been written in different directions, which may resemble the early Greek boustrophedon; it is not clear whether we can find a probable sign used to mark the word boundaries, or the text is in scriptio continua. There is no standard approved edition of the document and the readings of the document differ to a large extent between scholars, $c f$. Georgiev 1966, 7-23; Neroznak 1978, 30f.; Schmitt-Brand 1981, 41-47; Rasmussen 1999, 280; Dimitrov 2009, 3-13, $c f$. reading by Rasmussen KA $\Sigma$ II $\Lambda$ ETE $\Delta$ II $\Gamma E$ II EПI $\triangle$ AKATPOM OEBA) OZE $\Sigma$ AM II H ETENAREKOA II B $\Lambda$ ABAH).

13 Cf. Fraser 1960, $120 \mathrm{f}$.

14 A small golden ring bearing an inscription was found in 1925. In the middle the ring features an image of a horseman turning left and an inscription surrounding the image, which is to some extent damaged, so that, out of the probable total number of 21 signs, only 16 are readable. The text is written in the Greek (apparently Ionic) alphabet and

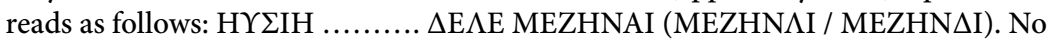
convincing interpretation and no standard edition exist. Especially important seems the 
tions with the same sequence $\Delta \mathrm{A} \Delta \mathrm{A} \Lambda \mathrm{EME}$ on silver phialae found at Bašova Mogila, near Duvanlii.

Last but not least, 75 graffiti on pottery have been recovered from the sanctuary of the Great Gods in Samothrace and c. 220 graffiti fragments on pottery written in an unknown language, probably a form of Thracian found in the sanctuary of Apollo in Zone on the coast of the Aegean. ${ }^{15}$
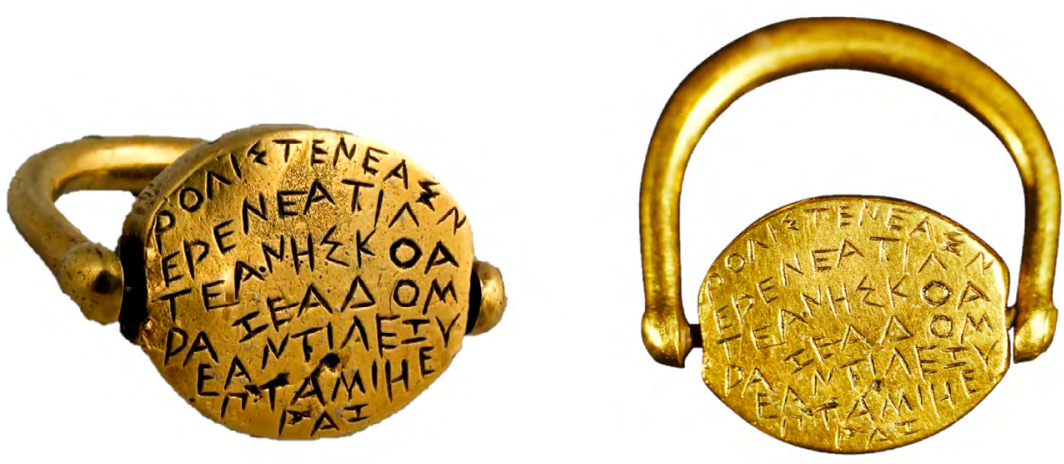

Figs. 9-10. Golden Ring from Ezerovo, first half of the $5^{\text {th }}$ cent. BC (National Archaeological Institute with Museum Bulgarian Academy of Sciences in Sofia; inv. No. 5271) (@Nikolaj Genov / Bulgariana).

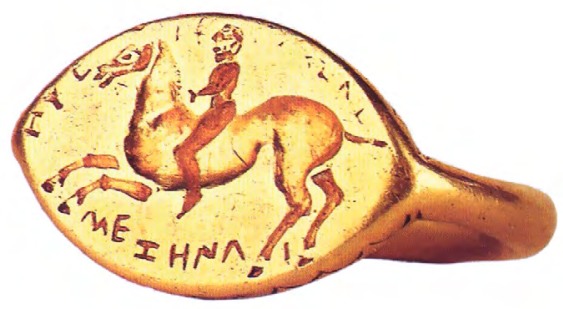

Fig. 11. Golden Ring from Ezerovo, first half of the $5^{\text {th }}$ cent. BC (National Archaeological Institute with Museum Bulgarian Academy of Sciences in Sofia; inv. No. 5271) (@Nikolaj Genov / Bulgariana).

attested use of the sign "eta" (the same in Ezerovo ring and Kjolmen inscription), with an unknown phonological value (long /e/? or some other vowel?) and an archaic form of a letter "zeta". Because of the image of a horseman, it has been assumed that the form MEZHNAI should be interpreted as dat. sg of a "to the horseman-deity" ( $c f$. archaeologically widely attested cult of the so-called "Thracian Horseman") and, according to Georgiev, the name should be related to the Messapic (Salentian) epithet of Iuppiter Menzana ('Horse Iuppiter'), a 'horse deity'. Further, hypothetical connections with Albanian Tosk mëz, Gheg maz, mãz ('male foal of a horse or donkey') and Romanian mânz ('colt, foal') have been tentatively postulated. This relationship seems, however, too speculative, and the Albanian forms may well be explained more plausibly as a derivation within Albanian itself. The form MEZHNAI (and the whole inscription) should be then treated as obscure, since we cannot even be sure if we are dealing with one or two words, $c f$. Detschev 1976², 291; Georgiev 1983, 1160f.; Dimitrov 2009, $16 f$.

$15 C f$. the description of the material and the archaeological site in Brixhe 2006, 121-146. 


\section{The relationship with Greek culture and language}

Even if the written evidence for vernacular language used in Thrace in antiquity is very scarce and limited to a few obscure inscriptions, the region has never remained isolated and thus benefited from the development of literacy in the regions further South, i.e. in Greece. The early presence of Greek colonies on the Thracian coast (both in the North Aegean and on the Black Sea shores from the archaic period onwards) and relatively high degree of penetration of Greek material culture into the Balkans (attested by archaeological findings) had contributed to the introduction of Greek script into the lands of Balkanic tribes. The domination of Greek culture, especially in Hellenistic period and then the Roman expansion into the Balkans, has left traces in numerous inscriptions in both Greek and Latin, exhibiting from time to time some local elements (e.g. personal names).

It seems that, although during the Imperial period Thrace as a Roman province kept the preference for the use of the Greek alphabet, the epigraphic sources exhibit a relatively high degree of Greek-Latin bilingualism. The attested inscriptions reflect complex socio-linguistic relations, as e.g. the presence of Roman military colonies in the neighbourhood of Philippi, where the epitaphs composed in Latin but written with Greek letters may be found.

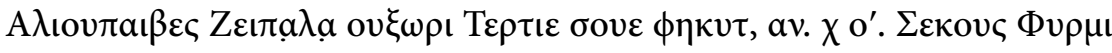

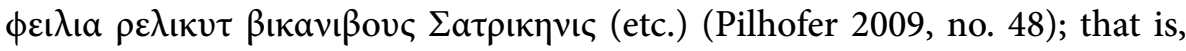
in the Latin transcription, Aliupaibes Zeipala $<$ filius $>$ uxori Tertiae suae fecit an(no) ch(oloniae) LXX. Secus Firmi filia reliquit vicanibus Satricenis (etc.), so "Aliupaibes, son of Zipala, made (the monument) for his wife Tertia, in the $70^{\text {th }}$ year of the colony. Secus, daughter of Firmus, left to the Satriceni villagers" (etc.) (Dana 2015, 244).

We do not of course know if the knowledge of Thracian as a means of everyday communication was already limited to more secluded areas outside the military and political-economic centres.

All Thracian indigenous inscriptions have been written in the Greek alphabet, the use of which is quite homogenous and consistent; no signs which do not come from the Greek alphabet have been attested so far. One may speculate as to whether the adoption of the alphabet was a uniform process - the limited number of inscriptions does not allow us to claim anything for sure, but one might distinguish at least two palaeographic zones: 
a) The first zone would comprise the epichoric alphabets with an archaic shape of letters, as e.g. used in Kjolmen inscription and in other inscriptions from Thrace proper.

b) The other zone would contain examples of the use of a Greek script in the North Aegean, in the Zone-Maroneia region on the coast and on the Island of Samothrace. If the epigraphic material found really yields the texts written in a form of a Thracian language, this script is distinct from the previous type (cf. slightly different classification by Dana 2015, 244f.).

All such features would link the script used in Thracian inscriptions to the very archaic stage of the development of Greek alphabets. If one treats the absence of the signs, which are current in the "blue" alphabets (Naxos, Paros, Thasos, Attica), as a phonological phenomenon of the adaptation of the script to Thracian language, the "Parian" hypothesis would be plausible. What one could state with a relative degree of certainty is that the introduction of the Greek alphabet to the Balkans must have occurred at the early point of archaic history. Of course, the systematic study of possible ways of penetration of script to the regions north of the Mediterranean would be a desideratum, especially if one could consider the parallels from other cultures. A certain degree of influence from the Phrygian culture, which seems to retain the cultural bonds with its Balkan homeland in the archaic period, is always a possibility.

It seems, however, that, considering the evidence, the application of Greek script in Thrace, unlike in the other cultural contexts, should be considered a local experiment rather than a long-lasting cultural legacy, and was very quickly superseded by Classical and Hellenistic, later also by Latin inscriptions (Dana 2015). ${ }^{16}$

16 The reasons for such a situation are obscure. According to Brixhe 2018, 1853 "in the $6^{\text {th }}$ century this (i.e. Thracian) language is surprisingly close to Greek". One might think of the more or less similar situation with Ancient Macedonian, which has never become a written language (irrelevant if it was 'just' an Ancient Greek dialect or a separate but a closely related vernacular to Greek), but the Macedonian territory yields a huge number of documents written in Greek language. 


\section{Onomastics}

Even if Thracian itself is poorly attested, we still have a considerable amount of onomastic material: personal names, place names, names of rivers and mountains, attested in vernacular inscriptions, Greek and Latin epigraphic testimonies from the Balkans, and in ancient literature. One may also add here the coin legends and attested names on artefacts, as e.g. on elements of

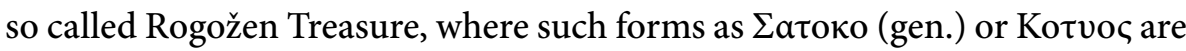
attested on the silver goblets.

This material can play an important role in interpretation of Thracian, especially the compound names, due to the attestations of many lexical elements, which may be then postulated as existing in spoken Thracian vocabulary. As usual, the analysis relies on etymological approaches, and the results must be treated with caution. Existing claims, according to which extant Slavonic river-names continue the same semantic pattern as forms attested in the Antiquity, and therefore allow for etymological-semantic interpretation of the original Thracian names are generally not to be treated as convincing. Consider, e.g. the name Črna reka (Black River), which seems to be the name of the river called in Antiquity'Epi $\gamma \omega v$, but it does not seem so certain that this fact allows us to postulate the existence of Thracian stem erig- from ${ }^{*}$ ereg $^{\prime \prime}$ (but $c f$. IE ${ }^{\star} h_{1} r e g^{\prime \prime}-$ ) as in Gr. है $\rho \varepsilon \beta o c$. Such assumptions are hazardous because, as we have already seen above, we hardly know the phonological development of Thracian, we are not sure that the interaction between Slavic speaking folk and the speakers of Thracian indeed took place, and a systematic stratification of Balkan onomastics is lacking.

\subsection{Anthroponymy}

It seems that, even if somehow similar to Illyrian or Messapic, the onomastic system of Thracian is considerably different and yields an archaic type of compound names, characterized by a morphological conservatism resembling a stage which had been commonly assumed for the Proto-Indo-European stage. Such situation could link Thracian more closely to ancient Greek dialects and less closely to Phrygian, which, except for one name, does not seem to use the same type of names.

Even if Thracian names are relatively frequent, they still form but a fragmentary system. It seems that from the point of view of word-formation we may recognize the continuants of $-i$, and $-u$ stems in the first member of com- 


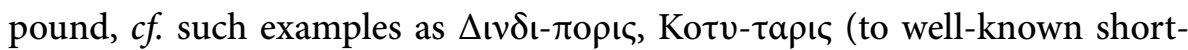

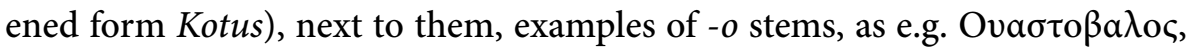
stems in long $-\bar{a}, c f . \Delta \alpha \lambda \eta-\pi о \rho ı \varsigma ~-~ w i t h ~-\bar{a}$ stem in the first, or $\Delta \rho \alpha \sigma$ - $\mu \alpha \rho \kappa \alpha$ - in the second member of a compound, or even -ia stems in $\Delta \iota \zeta \alpha-\tau \varepsilon \lambda \mu \iota c$. It seems further that one may find a type with preposition in the first member, if

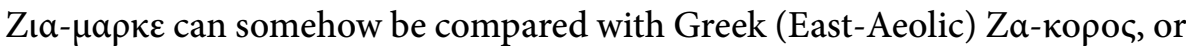
Gaulish $\Delta \mathrm{\iota} \alpha-\tau \alpha \rho o c$. On the other hand, it is must be admitted that most of the attested names remain obscure to us, especially from the etymological point of view, including a tentative name attested in Ezerovo ring inscripiton Rolisteneas or the whole list of Thracian royal names, as Teres, Sparatocos, Sitalces, Seuthes, Hebryzelmis, Ketriporis, Skostodokos, Kersivaulos, Rhescuporis, Rhoemetalces, etc. Even if we may see the inner structure in some of them, as e.g. in Sital-ces, or Ketri-poris, we lack any point of reference which would enable us to compare them with the existing etyma or formations attested in other Indo-European languages (for the description of Thracian anthroponymy $c f$. Milewski 1969, 53, 57, 68 and 80).

The original Thracian names are pretty well attested in Greek and Roman epigraphic documents form the region, but we lack any reliable information about the original naming practices. The current way of enumerating forefathers seems to be attested; $c f$. the inscription from $c a$. year $19 \mathrm{CE}$ "to Demeter dedicate this altar for the salvation of King Rhoemetalces and Pythodoria of Pontus, daughter of the son of King Rhoemetalces Kotys, and their children, Apollonius, son of Eptaykent, strategist (in the arena) of Anhialo". As we can see in this document, the traditional, royal names (Rhoemetalces, Kotys, Eptaykent) occur side by side with Greek (Pythodoria), but the youngest (Apollonius) already uses the Roman system of tria nomina (but not in this Greek text) and calls himself already Caius Iulius Apollonius. This testifies to progressed Romanization (Hellenization) of Thracia.

\subsection{Placenames}

Most Thracian place names attested in the ancient sources also seem to continue the inherited pattern of compound names, the number of elements used in formation of Thracian place names is relatively high, some of them have been well identified, as e.g. -bria,-diza, -para, -sara, etc. - especially in the names of prominent Thracian cities/settlements. Therefore, we interpret these elements as 'city' or 'town' -dava, -deva - typical for regions more to the North, $c f$. above the discussion on Dacian), an element probably with the 
same meaning -bria 'town, city, fortified settlement', -diza, -dizos 'fortress, walled settlement', or -para 'town, village'. In many cases those elements had been translated by Greek authors as -polis, cf. Pulpudeva - Фı $\lambda_{\imath} \pi \pi$ óло $\lambda_{\iota}$ but certainly the semantic distinction was present. As already pointed out above -diza may actually continue the inherited Indo-European stem ${ }^{*} d^{h} e i g^{h}$ - and could be referred to the Greek $\tau \varepsilon \tilde{x} \chi \varsigma^{\circ}$ 'wall', thus expressing the idea of a fort or a fortified town, whereas - bria (Melsambria, Gk. Meøí $\mu \beta \rho ı$, $c f$. Bulg. Nesebyr), seems to have been related to Toch A and B ri, ryie (from * urih ${ }^{-}$), probably in the original meaning as 'town (settlement) on the hill'. It may however be true for Thracia that in historical times -dava and -bria already meant two different things in the same language ( $c f$. the difference between city and town): e.g. -bria might have been used for urbanized settlements resembling those of Greeks, whereas -daval-deva 'settlement, town" $\left(<{ }^{*} d^{h}(e) h_{1}-u \bar{a} \overline{-}-\right.$, to $\mathrm{IE}^{\star} d^{h} e h_{1}$ - 'set, lay') could mean a settlement situated in rural, the steppe-like part of Thracia, but the real meaning still remains obscure (Duridanov 1985, 124-127; cf. also Matzinger 2016, 32). 


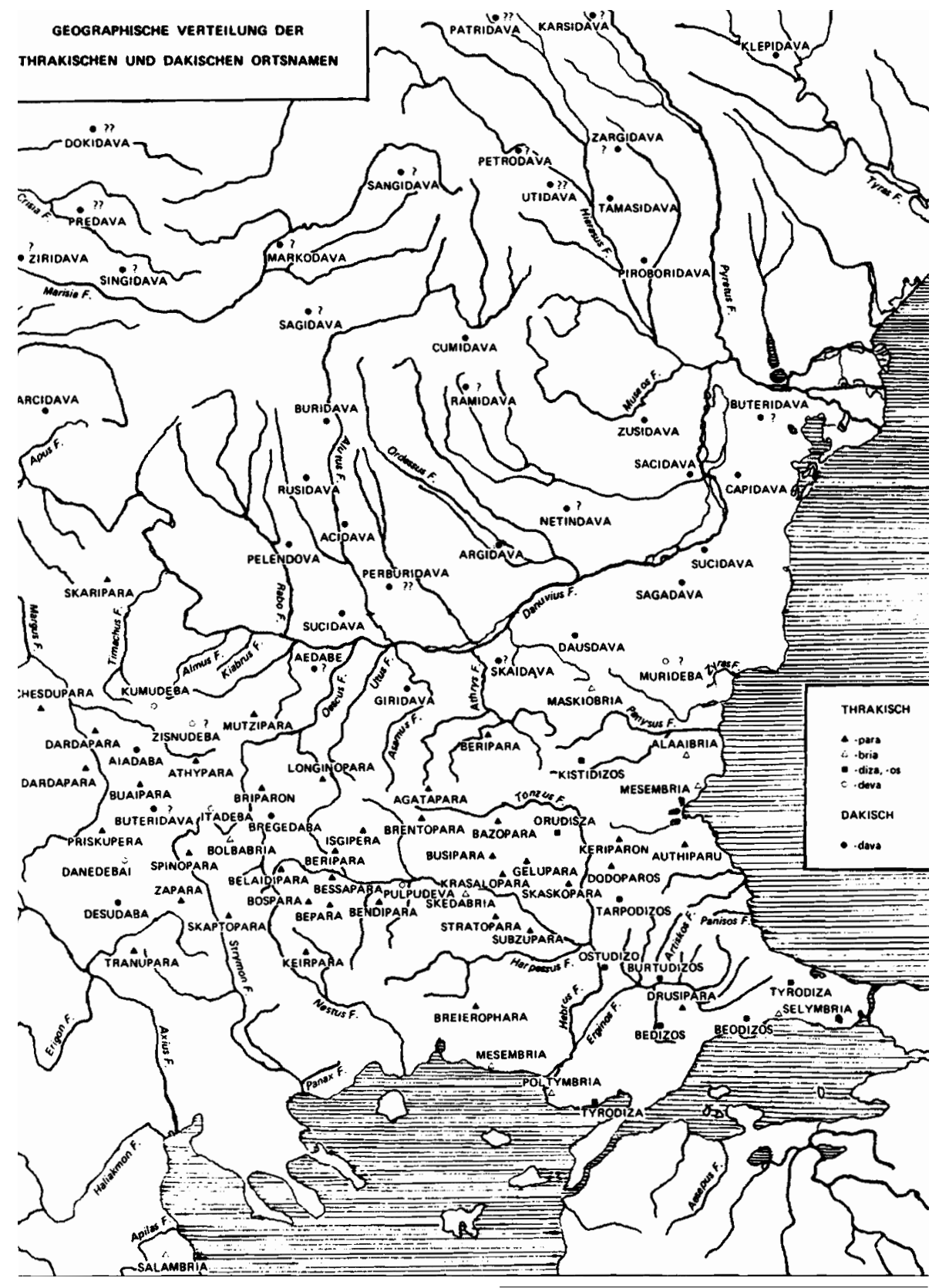

Fig. 12. The distribution of Thracian and

Dacian place-names (Duridanov 1985, 151). 


\subsection{Tribal names}

Due to the close relationships with Greeks there are also plenty of various tribal names (ethnonyms) from Thracia attested in ancient literature, but also in historical inscriptions. In most cases they can be classified as ethnonyms derived from place names, as e.g. Mygdones (Strab.) were named after the region of Mygdonia (which, on the other hand, had been derived from, as it seems, a personal name Mygdon). They can also point to the features of particular surrounding landscapes, as may be the case of a name mentioned by Thucydydes, Пaváıo, which may reflect the original *pon- or similar, meaning "a swamp, bog" and present in Thracian river names already with a Thracian change of ${ }^{\star} o>a$ (see above). The same naming practice - referring to the landscape seems to be present in the name of Odrysai/Odrisi/Odrysae (Liv.) if it really should be interpreted as ${ }^{\star} h_{2} o-d r u-s^{\circ}$ 'inhabitants of forest' (see above). The other names seem at the first glance to have totemic origins; for example, the name of the tribe of Bebrykes around Bosphorus, looks like it is related to the word for beaver, so 'The Beavers'; other tribe names seem to be derived from prized qualities; this may be the case of Darsioi/Dersaioi if the name really can be related to OInd. dhrșnú- 'brave, audacious, bold'; $c f$. Avest. daršvyu- 'brave, strong' (IE ${ }^{*} d^{h} r s$ - 'brave'), it may be explained as 'The Brave ones". On the other hand, the tribe name of the Kikones, Cicones, whose women are famous for killing the Thracian poet Orpheus according to some scholars should be linked to such forms as OHG queh, quek 'alive', Anglo-Saxon $c$ wicu and ultimately interpreted as ${ }^{\star}$ gigō(n)es 'quick ones, agile ones' (cf. e.g. Duridanov 1985, 67). It seems however that such an interpretation poses more problems than it solves, e.g. the question of a consonantal mutation, the treatment of labiovelars, since the Germanic examples are easily to be understood as derivatives from the IE 'live' $\operatorname{root}^{*} g^{\prime \prime} e i h_{3}-$.

Even if in many cases one may find some interesting etyma and if their etymology looks plausible, it is necessary to support this etymology with semantical parallels, which are still in many cases missing. The material seems to yield many graphical/phonetical differences (see above), lead to the conclusion that we distinguish about at least four onomastic zones, including Thrace and West-Thrace on the one hand as a core area, and related, though slightly different areas of Dacia (Dacia-Mysia) and Bithynia in Asia Minor (Dana 2014, LXIII-LXXXII). These observations would essentially confirm the existence of different dialects within Thracian language. 


\section{The research on Thracian language and epigraphy}

The biggest obstacle while studying Thracian is the nature of its documentation. The fragmentary attested evidence for this language hinders almost every aspect of research done on the Thracian language and culture - due to the lack of intelligible epigraphical or original literary evidence, one has to understand the limits of possible interpretation of the language itself, its filiations and its historical development. The amount of 80-90 glosses quoted by the ancient sources as Thracian (which may be increased by about 60 Dacian plant names - if they really express some sort of linguistic reality, cf. Brixhe 1997, 190; Velkova 1986) is not enough to propose any convincing claim about the nature of Thracian speech. The following section tries to summarize the biggest challenges occurring in the study of the language and the epigraphic culture of ancient Thrace.

In the case of the language spoken by the Thracian tribes, one has to emphasize that it is the classical example of the fragmentary attested language; the scarcity of the material prevents us from undertaking systematic studies. The isolated pair of Thracian inscriptions still remain enigmatic. The essential claims about the nature of Thracian have been made exclusively on the basis of the examination of secondary sources: the glosses (i.e. the forms noted and transmitted as "Thracian" by the ancient, mostly Greek, authors); and onomastic material, attested both in Greek and, to some extent, also Latin inscriptions from the region, and in the Greek and Latin literary sources. All these limit our possibilities to apply the methodology of historical-comparative linguistics, where the so-called "fragmentary attested languages" have a special status. We use this term: 1) to refer to languages that were in full use at the time of their documentation, but whose attestations nonetheless cannot yield the coherent picture of their grammatical system and vocabulary; 2) to refer to languages that already in period of their documentation were no longer in full use (Matzinger 2006, 190). Systematic interpretation of such language is difficult primarily because our knowledge is based only on secondary information (mostly form ancient sources), glosses, and onomastic material. Further problems appear if we attempt to arrange these fragmentary languages into suitable language groups according to the criteria of linguistic relationships. Completely different and very often contrary opinions on the nature of such languages often result from "etymological" interpretation of very meagrely attested material ("root etymologies"). This kind of interpreta- 
tion depends on postulating etymologies for the singular attested forms, based on comparison to other forms from better known or better attested languages. Conclusions based on this approach remain always very problematic, because most of the material remains in the domain of proper names to which no specific "meaning" can be ascribed.

Leaving aside the problem of interpreting the sources of the forms quoted by the ancient scholars as "Thracian", one has to bear in mind the possibility of various external influences from the languages spoken by the authors (mostly various Greek dialects) on transmitted material. Among the factors to be considered are: 1) various forms of morphological adaptation into Greek (or Latin); 2) the problem of rendering the Thracian phonology and phonetic reality with the help of a Greek alphabet (with changing phonetic value in Greek itself, depending on the chronology); 3) other forms of

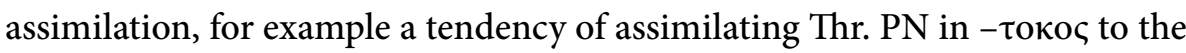

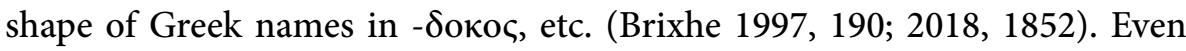
if we assume that, especially in Hellenistic and Roman periods, some of the authors of inscriptions might have been of native Thracian stock (or bilingual at least), the above-mentioned problems still hold. The limitations of chosen orthography (Greek or Latin) do not allow for phonetic accuracy, especially if we keep in mind that Thracian evolved as well: this is probably why we find various orthographies, e.g., Thr. ${ }^{\star} \bar{u}$ very probably developed towards [ü] and $[i]$ leaving the traces in various conventions of writing ( $c f$. $\beta \rho \circ \tilde{\tau} \tau o \varsigma: \beta \rho \tilde{v} \tau o \varsigma$ 'sort of Thracian beer' $<{ }^{\star} b^{h} r u H t o$ - from IE ${ }^{\star} b^{h} r e u H$ - 'ferment' (cf. Eng. brew); the place name Surascele : Syracella : Sirogellis; the name of a famous tribe

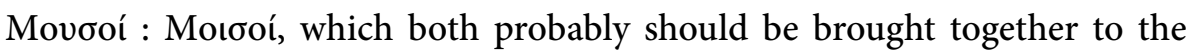
same phonetic interpretation as [misoi]) (Detschev 1957, 486; Brixhe-1997). ${ }^{17}$

There is no doubt that the Thracian belongs to the Indo-European linguistics family, but as such it does not seem to have any close cognates with which it would form a separate language group or branch. Judging from the historical perspective, Thracian should be very probably interpreted as a part of so called "Balkan Indo-European" continuum, either as a cognate or through geographical proximity. This hypothesis essentially proposes a common period of prehistoric coexistence of several Indo-European dialects in the Balkans prior to $2000 \mathrm{BC}$., although several tribes could identify themselves

$17 C f$. the examples of orthographic fluctuations in writing Thracian names gathered by Dana 2014, XCV. 
as separate ethnic units nevertheless. To this group would belong Ancient Greek, Phrygian, Armenian, Albanian, as well as fragmentary attested languages such as Macedonian, Thracian, or Illyrian and (relatively well attested) Messapian (attested in historical times in South Italy). ${ }^{18}$ The common features of the Balkan Indo-European appear at the phonological, morphological, and lexical levels. One may assume that they result from the contact between the various languages. The concept of Balkan Indo-European should be understood as a specific areal-linguistics phenomenon - a kind of spaceband (language league) of the Bronze Age - even though it consisted of languages that were related to each other. It seems, moreover, that at least for Greek, Macedonian, and Phrygian (and, according to some scholars, Armenian), one may reconstruct a single proto-stage, pointing to one common, prehistoric dialectal continuum in late Indo-European. ${ }^{19}$ This assumption may help to interpret some of the phenomena. However, given that, except for Greek, all other languages of the region are either fragmentary attested, or documented much later (Albanian), or developed in other geographical-linguistic circumstances (Armenian), this theory, though very interesting, cannot be broadly applied here. ${ }^{20}$ It seems however that such an assumption of the common linguistics origins in pre-historic period somewhere in the Balkan could help to shape the way for future research. In theory any aspect of the common linguistic heritage, as e.g. claimed for Phrygian or Ancient Greek could have an impact on the Thracian language.

As already pointed out our comprehension and understanding of grammatical system of Thracian is limited, the current knowledge of the language makes any translation of attested inscriptions impossible.

Due to already presented scarcity of the evidence, it is difficult to systematize the problems and challenges connected with epigraphic context of Thracian. On one hand one may hope that new texts may be revealed in fu-

18 For the brief introduction into the hypothetical Balkan Indo-European see Klingenschmitt 1994, 244f.; Matzinger 2005, 381-386; Sowa 2005, 611-628, cf. also Hajnal 2003, 117-145 for methodological considerations.

19 Hajnal 2003, 135; Ritter \& Sowa 2004, 646f.; Matzinger 2005, 381-385; Sowa 2005, 611-614.

$20 C f$. Brixhe 2018, 1853, who more or less agrees with aforementioned hypothesis (unfortunately without mentioning any existing literature on the problem): "in the period between Proto-Indo-European and the emergence of Greek, Thracian, and Phrygian, it is probably necessary to posit a linguistic conglomerate to which the populations which were later to develop into Greeks, Phrygians, and Thracians belonged". 
ture as the result of intensified archaeological works currently being recently carried out in Bulgaria (after joining the European Union in 2007), which practically every year yield new findings (though until now the epigraphical findings are exclusively Latin and Greek inscriptions), and on the other hand it is still possible that the progress in studying development and history of the Greek script (particularly outside Greece) may provide us with new data which may be relevant for interpretation of Thracian inscriptions. In fact, the study of ways using which Greek script (or the alphabet) had penetrated the Balkans seems the crucial challenge for future research.

It is interesting to ask which regional variation of the Greek script became the source for the alphabet adopted in Thrace. We might tentatively claim that the use of script in Thrace might have been spread along various cultural routes. Some scholars point to the alphabet used on the island of Paros as a possible source (Dana 2014, 257). The island is famous for the colonization of Thasos where the Greeks came into direct contact with Thracian. The assumed use of a "crescent moon beta" (cf. e.g. J) is cited as evidence, and the documents in the Parian alphabet have been found on the island of Thasos, not far away from the Thracian shores (cf. e.g. Tiverios 2011, 317-329). This seems to hold true for coastal regions and for Samothrace; it must be stated, however, that both of the two longest inscriptions known from Thrace do not exhibit the "specific" features which could be linked to the so-called "pale blue" Greek alphabets, as known from Paros, Naxos, Thasos (and also Attica), where one observes the use of such signs as phi $\Phi$ for an aspirated $/ \mathrm{p}^{\mathrm{h}} /$, khi X for an aspirated $/ \mathrm{k}^{\mathrm{h}} /$ and where a general absence of such signs known from classical attic as ksi and psi can be observed (Jeffery 1961, 291ff.). Such consonant clusters have been rendered in those regional alphabets by a combination of phi and khi with sigma instead, in the archaic period, $c f . \Phi \Sigma, \mathrm{X} \Sigma$, or even by using a

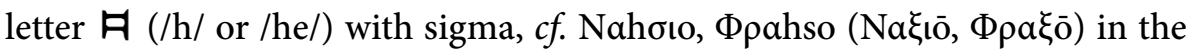
so-called dedication of Nikandre (inscription incised on the archaic statue of Artemis form Naxos; dated for $7^{\text {th }} / 6^{\text {th }}$ cent. BC., IG XII, 5, 2 p. XXIV). ${ }^{21}$

On the contrary, the Thracian orthography from both mainland Thrace and Zone-Samothrace does not seem to include the signs for aspirated stop $\langle\Theta\rangle,\langle\Phi\rangle,\langle\mathrm{X}\rangle$, and the "crescent moon beta" is not recorded, whereas one finds a constant use of a regular beta sign. There is no distinction between long and short vowels - no sign eta $<\mathrm{H}>$ and omega $<\Omega>$ is attested. There is

\footnotetext{
$21 C f$. the discussion in Schwyzer 1939, 211; Lejeune 1972, 72f.; $88 f$.
} 
a distinction to be observed in the application of the "yod" sign. It has been used both to render the vowel /i(:)/ and a glide /i/ in Thrace, but it seems that in "coastal" alphabets in Zone and Samothrace two "yods" occur, a "normal" and a "serpent" variant, i.e. I and Z - the first in its classical function, as a vowel sign, a glide, or a non-syllabic element of a diphthong, whereas the second sign is attested certainly in a context limited to the two latter ones. This could corroborate the hypothesis that in the early phase of transmission of the Semitic alphabet to Greek and related scriptures, a vowel ${ }^{\star} / \mathrm{i}(:) /$ and a glide ${ }^{\star} / \mathrm{i} /$ have been noted by one sign, a simplified version of a Semitic "yod": $\chi$, which has been then split. Early Greek script has retained the memory of this phase, preserving the two iotas $Z$ and I, a situation which has then changed with the phonetic development of $* / \mathrm{i} /$ in various dialects of Greek, resulting in eliminating the symbol for glide yod. It seems that at least traces of this phase can be still found in the written variant in Zone and Samothrace; it is, however, unclear why this was simplified in the Greek way in mainland Thrace. ${ }^{22}$

The inscriptions from Zone and Samothrace sporadically exhibit a use of a specific sign $\mathrm{w}$ which may resemble a shape of a Greek psi letter, but as already pointed out above, such orthography is not attested on Paros or Naxos. Of course, it is possible that it may be a regional sign used for some consonant cluster, for example $[\mathrm{ks}]$, since the "Naxian" variant of orthography $A \leqslant[\mathrm{hs}]$, due to absent eta sign, was not possible. ${ }^{23}$

22 The idea has been repeated several times by Brixhe ( $c f .2004$, and 2007 with review of this idea), mostly in the context of Phrygian. Brixhe suggests that the script repertoires did initially possess a single sign, an "avatar of the simplified Semitic yō $<>>$ " and he assumes a use similar to those of waw (as vowel or glide). At some time before the first written documents (i.e. before $8^{\text {th }}$ cent. $\mathrm{BC}$ ) one of the languages might, for the vowel articulation, have created a second sign out of an existing one, by "amputating its lateral appendages $<\mathrm{I}>$ ”. Because in archaic, post-Mycenaean Greek the palatal glide /i/ did not have a status of an independent phoneme, it must have been the Phrygian language, for which this creation fulfilled an actual need. The limited presence of two iotas in various regional variants of the Greek alphabet could be then considered a Phrygian contribution to the elaboration of the alphabet (Brixhe 2006; 2007, 280f.). Given the certain cultural proximity and assumed certain sort of linguistic affinity between Thracians and Phrygians one could ask if the Phrygian culture could have played some role in the process of introducing script into the Balkans - it seems that the Phrygians had preserved the knowledge of their Balkan origins and they had kept the close links to the Greeks through their history so such an assumption would seem an interesting alternative.

23 For the problem of Ionic /e:/ and the orthographical practice see e.g. Thumb 1909, 346f.; Heubeck 1979: 124; Miller 101f.; Schmitt 1977, 101. It seems that without the systematic attempts to decode the Thracian spelling as rendered by Greek character no interpretation of the documents will be possible. For example, if we consider the initial form PO $\Lambda$ I $\Sigma T E N E A \Sigma$ (Ezerovo) a personal name formed in the similar way as the Greek 
Thracian inscriptions have never been published in the form of a modern corpus, and the existing studies mostly refer to the individual publications by Georgiev, Detschev or Neroznak (during the time span between 1938 till 1980's). No critical edition exists, no detailed photos have been made recently and the complete edition of the material from Zone is not yet ready. One has to emphasize however that even if no official printed corpora for the Thracian inscriptions exist, there are many publications treating epigraphical documents from Thrace, written in other languages, namely Greek and Latin, cf. volume 3 of Corpus Inscriptionum Latinarum, and a new regional corpus covers the western part of Lower Moesia (B. Gerov, ILBulg, 1989). Many more numerous Greek inscriptions from Bulgaria have been edited in the corpus of G. Mihailov (IGBulg, 1958-1997) and the material form North Aegean has

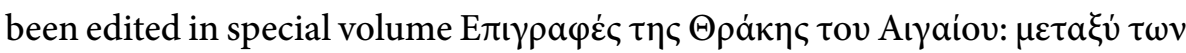

compound names, one could probably assume that this personal name contains the element -stenes, which should then be interpreted as an equivalent to Greek - $\sigma \theta \dot{\varepsilon} v \eta \varsigma$ "strong" known from such names, as e.g. Demosthenēs. Since the Greek form yields a long vowel /e:/ one would ask whether the Thracian orthography $<\mathrm{EA}>$ could not be treated as an alternative spelling for the long vowel (instead of assuming here a sort of -io- derivation [Rolistenias]). Of course, this assumption may appear problematic considering the attestations of a letter "eta" in this inscription. It seems, however, that the question is well justified, especially if one admits the role of the Central Ionic alphabets in spreading the culture of writing to the regions in the north of Aegean. In Central Ionic archaic inscriptions, written is so called "pale blue" alphabet, the Ionic change of ${ }^{\star} / \mathrm{a}$ :/ > /e:/, is realized in orthography with the sign $<\mathrm{H}>$ (also after /e/, /i/, /r/):

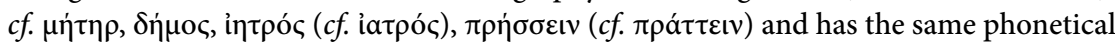
value as the etymological ${ }^{\star} / \mathrm{e}: /$ (and is quite inconsistent in script, $c f$. used signs $\mathrm{E}$ or $\mathrm{H}$ ). In documents from islands of Naxos and Keos, however, different orthographies in archaic material may be found, which could ultimately point to a preserved phonetical difference between the inherited long /e:/ and the secondary long/e:/ a product of a typical Ionic sound change. Until $5^{\text {th }}$ cent. $\mathrm{BC}$ A, $\mathrm{H}=[\mathrm{e}:]<* / \mathrm{a}: /$ and $\mathrm{E}=[\overline{\mathrm{e}}]<* / \mathrm{e}: /, c f$.

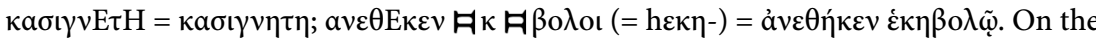
other hand, if one examines the inscription from Kjolmen then one of the most important issues concerning this document is the interpretation of three variants of a sign rendering /s/, namely $\{, \zeta$ and $\xi ;$ while this usage would generally fit the Greek evidence found in various regional usage of the archaic alphabets, where different signs for $/ \mathrm{s} /$ are attested, we don't know why the author of the text chose various shapes of that letter. Rasmussen for example suggests that the letters should be given other phonetical values, namely $/ \mathrm{s} /, / \mathrm{n} /$ and $/ \mathrm{m} /$ respectively, otherwise one should claim the existence of various sibilants in Thracian. The document yields another interesting phaenomenon, namely possible use of a dot for /o/, which is attested in Greek inscriptions only in Mycenae in the $5^{\text {th }}$ cent. BC, and is otherwise an unknown practice. Moreover, the use of a lunar sign ) as a sort of punctuation, which is known from the documents from Peloponnesus exclusively. Such comparisons challenge the interpretation presented above and suggest the writing in Thrace shouldn't be necessarily related to the Central Ionic colonies and their tradition of alphabet. 


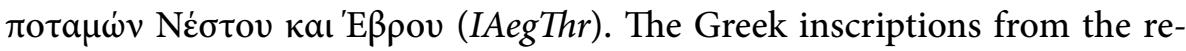
gion are now accessible online as a part of Searchable Greek Inscriptions project (The Packhard Humanities Institute, $c f$. the entries under Thrace and the Lower Danube <https://inscriptions.packhum.org/regions/12>). As has been already suggested above, both Latin and Greek inscriptions contain valuable material mostly from the onymic area from Thrace, the study of orthographic conventions of this material can potentially bring new results which could then be applied to Thracian epichoric material.

\section{$\begin{array}{llllllllllll}\mathbf{B} & \mathbf{I} & \mathbf{B} & \mathbf{L} & \mathbf{I} & \mathbf{O} & \mathbf{G} & \mathbf{R} & \mathbf{A} & \mathbf{P} & \mathbf{H} & \mathbf{Y}\end{array}$}

Anreiter 2001: P. Anreiter, Die vorrömischen Namen Pannoniens, Budapest 2001.

Best \& De Vries 1989: J. GP. Best and N.M.W. de Vries (eds.), Thracians and Mycenaeans. Proceedings of the Fourth International Congress of Thracology, Rotterdam 24-26 September 1984, Leiden-Sofia 1989.

Boardman et al. 1991: J. Boardman, I. E. S. Edwards, E. Solbelger and N. G. L. Hammond, The Cambridge Ancient History, Volume III, Part 2: The Assyrian and Babylonian Empires and other States of the Near East, from the Eighth to the Sixth Centuries B.C., Cambridge 1991.

Brixhe 1997: C. Brixhe, "Le thrace", in: F. Bader, Langues indo-européennes, Paris 1997, 181-205 (with A. Panayotou).

Brixhe 2004: C. Brixhe, "Nouvelle chronologie anatolienne et date délaboration des alphabets grec et phrygien", Comptes-rendus des séances de l'académie des Inscriptions et BellesLettres 148/1, 2004, 271-289.

Brixhe 2006: C. Brixhe, "Zôné et Samothrace: lueurs sur la langue thrace et nouveau chapitre de la grammaire comparée?", Comptes-rendus des séances de l'académie des Inscriptions et Belles-Lettres 150/1, 2006, 121-146.

Brixhe 2007: C. Brixhe, "History of the alphabet: Some guidelines for avoiding oversimplification", in: A.-F. Christidis, A History of Ancient Greek, Cambridge 2007, 277-287.

Brixhe 2018: C. Brixhe “Thracian”, in: J. Klein, B. Joseph and M. Fritz (eds.), Handbook of comparative and historical Indo-European Linguistics, Berlin-Boston 2018, 1850-1854.

Crossland 1982: R. Crossland "Linguistic problems of the Balkan area in the late prehistoric and early Classical periods", in: Cambridge Ancient History Vol. 3,1: The Prehistory of the Balkans; and the Middle East and the Aegean world, tenth to eighth centuries BC, Cambridge 1982, 834-849.

Dana 2014: D. Dana, Onomasticon Thracicum (OnomThrac). Répertoire des noms indigènes de Thrace, Macédoine orientale, Mésies, Dacie et Bithynie, Athens 2014.

Dana 2015: D. Dana, "Inscriptions", in: J. Valeva, E. Nankov and D. Graninger, A Companion to Ancient Thrace, Malden-Chichester 2015, 243-264.

Detschev 1957: D. Detschev, Die thrakischen Sprachreste, Wien 1957 [1976]².

Dimitrov 2009: P. A. Dimitrov, Thracian Language and Greek and Thracian Epigraphy, Newcastle-upon-Tyne 2009. 
Wojciech Sowa

Duridanov 1985: I. Duridanov, Die Sprache der Thraker, Neuried 1985.

Fraser 1960: P. Fraser, Samothrace. the Inscriptions on Stone, New York 1960.

Georgiev 1938: V. Georgiev, "Die Inschrift von Ezerovo", Zeitschrift für vergleichende Sprachforschung 65, 1938, 84-192.

Georgiev 1966: V. Georgiev, "Die Deutung der altertümlichen thrakischen Inschrift aus Kjolmen”, Linguistique Balkanique 11/1, 1966, 7-23.

Georgiev 1977: V. Georgiev, Trakite i technijat ezik, Sofija 1977.

Georgiev 1983: V. Georgiev, “Thrakisch und Dakisch", in: W. Haase (ed.), Aufstieg und Niedergang der römischen Welt; Teil: 2, Prinzipat, Bd. 29, Teilbd. 2. Sprache und Literatur, Berlin-New York 1983, 1148-1194.

Hajnal 2003: I. Hajnal, "Methodische Vorbemerkungen zu einer Palaeolinguistik des Balkanraums", in: A. Bammesberger and T. Vennemann (ed.), Languages in Prehistoric Europe, Heidelberg 2003, 117-145.

Heubeck 1979: A. Heubeck, Schrift, Göttingen 1979.

Jeffery 1961: L. Jeffery, The Local Scripts of Archaic Greece, Oxford 1961.

Katičić 1976: R. Katičić, Ancient Languages of the Balkans, The Hague 1976.

Klingenschmitt 1994: G. Klingenschmitt, "Die Verwandtschaftsverhältnisse der indogermanischen Sprachen", in: J. E. Rasmussen (ed.), In Honorem Holger Pedersen. Kolloquium der Indogermanischen Gesellschaft vom 26. bis 28. März in Kopenhagen, Wiesbaden 1994, 235-251.

Колев 2006: Р. Колев, Клады фракийцевл Каталог высабки. Издательство Славена, Варна 2006.

Lejeune 1972: M. Lejeune, Phonetique historique du mycénien et du grec ancient, Paris 1972.

Matzinger 2005: J. Matzinger, "Phrygisch und Armenisch", in: G. Meiser and O. Hackstein (ed.), Sprachkontakt und Sprachwandel. Akten der XI. Fachtagung der Indogermanischen Gesellschaft, Wiesbaden 2005, 375-394.

Matzinger 2006: J. Matzinger, "Interpretation sprachlicher Daten aus Rest- und Trümmersprachen. Das Fallbeispiel der Streitfrage um eine phrygische Lautverschiebung", Historische Sprachforschung 119, 2006, 190-210.

Matzinger 2016: J. Matzinger, Die altablkanischen Sprachen, Wien 2016.

Mihailov 1991: G. Mihailov, 1991 “Thrace Before the Persian entry into Europe”, in: Cambridge Ancient History, vol. 3.2: The Assyrian and Babylonian Empires and Other States of the Near East, from the Eighth to the Sixth Centuries B.C., Cambridge 1991, 591-618.

Milewski 1969: T. Milewski, Indoeuropejskie imiona osobowe, Wrocław-Warszawa-Kraków 1969.

Miller 2013: D. G. Miller, Ancient Greek Dialects and Early Authors, Berlin-New York 2013.

Neroznak 1978: V. P. Neroznak, Paleobalkanskije jazyki, Moskva 1978.

Neumann 1979: G. Neumann, “Thraker: Sprache”, in: Der kleine Pauly 5, München 1979, 781- 783.

Panayotou 2007: A. Panayotou, "Greek and Thracian", in: A. Christidis (ed.), History of ancient Greek Language from the Beginnings to Late antiquity, Cambridge 2007, 730-744.

Pilhofer 2009: P. Pilhofer, Philippi II. Katalog der Inschriften von Philippi, Tübingen 2009.

Polomé 1982: E. C. Polomé "Balkan languages (Illyrian, Thracian and Daco-Moesian)", in: Cambridge Ancient History Vol. 3,1: The Prehistory of the Balkans; and the Middle East and the Aegean world, tenth to eighth centuries BC, Cambridge 1982, 866-876. 
Rasmussen 1999: J. E. Rasmussen, "Die thrakischen Inschriften - Beiträge zu einer neuen Deutung", in: Selected papers in Indo-European linguistics, Copenhagen 1999, 276-287.

Ritter \& Sowa 2004: R. P. Ritter and W. Sowa, "Greek-Armenian Isoglosses and Ancient Greek Dialects", in: M. Margariti-Rogka, G. Papanastasiou and N. Liosis, Studies in Greek Linguistics 24, Thessaloniki 2004, 645-656.

Russu 1969: I. I. Russu, Die Sprache der Thrako-Daker, Bucharest 1969.

Russu 1979: I. I. Russu, "Die griechische und lateinische Schrift im vorrömischen Dakien (König Thiamarcos, Decebalus und Scorilo)”, in: D. M. Pippidi and E. Popescu (ed.), Epigraphica. Travaux dédiés au VII Congrès dépigraphie grecque et latine, Bucharest 1979, 33-50.

Schmitt 1977: R. Schmitt, Einführung in die griechischen Dialekte, Darmstadt 1977.

Schmitt-Brand 1981: R. Schmitt-Brand, "Die thrakischen Inschriften”, Glotta 45, 1981, 40-60.

Schwyzer 1939: E. Schwyzer, Griechische Grammatik. Bd. 1, München 1939.

Sowa 2005: W. Sowa, "Anmerkungen zum Balkanindogermanischen”, in: G. Schweiger (ed.), Indogermanica. Festschrift für Gert Klingenschmitt, Taimering 2005, 611-628.

Sowa 2006: W. Sowa, "Makedonische Glossen in Antiken Quellen", Studia Etymologica Cracoviensia 11, 2006, 115-133.

Sowa 2008: W. Sowa, Studien zum Phrygischen, Göttingen 2008.

Sowa 2009: W. Sowa, "Onomastik und die sog. Trümmersprachen: der Ortsname $\Sigma \varepsilon \rho \mu \eta$ ”, in: K. Loudova (ed.), Early European Languages in the Eyes of Modern Linguistics. Proceedings of the Colloquium on the Ancient Indo-European Languages, Brno 28 September - 1 October 2008, Brno 2009, 289-296.

Thumb 1909: A. Thumb, Handbuch der griechischen Dialekte, Heidelberg 1909.

Tiverios 2011: M. A. Tiverios, "An archaic alphabet on a Thasian kylix", in: G. R. Tsetskhladze (ed.), The Black Sea, Greece, Anatolia and Europe in the first millennium BC, LeuvenParis-Walpole a 2011, 317-329.

Tomaschek 1893-94: W. Tomaschek, Die alten Thraker. Eine ethnologische Untersuchung, Wien 1893-1894 (repr. 1980).

Valeva, Nankov \& Graninger 2015: J. Valeva, E. Nankov and D. Graninger, A Companion to Ancient Thrace, Malden-Chichester, 2015.

Velkova 1986: Ž. Velkova, The Thracian Glosses. Contribution to the Study of the Thracian Vocabulary, Amsterdam 1986. 